\title{
Influence of music on the level of physical fitness of the students practicing rugby (rugby players students)
}

\author{
Kozina Zh.L. ${ }^{1 \mathrm{ABCDE}}$, Kalinicenko V.E. ${ }^{\mathrm{ABCDE}}$, Cretu M. ${ }^{2 \mathrm{ADE}}$, Osiptsov A.V. ${ }^{3 \mathrm{CDE}}$, Kudryavtsev M.D. ${ }^{4,5,6,7 \mathrm{ADE}}$, Polishchuk \\ S.B. ${ }^{1 \mathrm{ABC}}$, Ilnickaya A.S. ${ }^{1 \mathrm{CDE}}$, Minenok A.O. ${ }^{8 \mathrm{CDE}}$ \\ ${ }^{1}$ Department of Olympic and Professional Sports and Sports Games, H. S. Skovoroda Kharkiv National Pedagogical \\ University, Ukraine \\ ${ }^{2}$ Faculty of Science, Physical Education and Informatics, University of Pitesti, Romania \\ ${ }^{3}$ Department of Physical Education and Health, Mariupol State University, Ukraine \\ ${ }^{4}$ Department of Physical Training, Krasnoyarsk State Pedagogical University of V.P. Astafyev, Russia \\ ${ }^{5}$ Siberian Federal University, Russia \\ ${ }^{6}$ Reshetnev Siberian State University of Science and Technology, Russia \\ ${ }^{7}$ The Siberian Law Institute of the Ministry of Internal Affair of Russia, Russia \\ ${ }^{8}$ Faculty of Physical Education, National University "Chernigiv Collegium” T. G. Shevchenko, Ukraine
}

Authors' Contribution: A - Study design; B - Data collection; C - Statistical analysis; D - Manuscript Preparation; E - Funds Collection.

\begin{abstract}
Purpose: $\quad$ to develop a training technology with the application of music at rugby training of 16-17-year-olds players.

Material: $\quad$ Rugby players $(n=20)$ from sports club "KhTZ" (16-17-year-olds) participated in a research. Athletes were divided into two groups: the control group $(n=10)$, the experimental group $(n=10)$. The experimental group trained with music. The groups were tested on the level of physical fitness at the beginning and at the end of the experiment. The following tests were applied: $30 \mathrm{~m}$ run, $400 \mathrm{~m}$ run, barbell press in a prone position (maximum value), $3 \mathrm{~km}$ run.

Results: It is defined the influence of music on physical fitness indicators of athletes. It is revealed a confident increase in indicators of the general endurance ( $3 \mathrm{~km}$ run) and special endurance ( $400 \mathrm{~m}$ run) in students of the experimental group. The students of the control group had a confident increase in result in $400 \mathrm{~m}$ but in smaller significance value.

Conclusions: The received data confirm the expediency of music application in young athletes' training for the development of the general and special endurance.

Keywords: rugby, music, endurance, strength, fitness.
\end{abstract}

\section{Introduction}

The kinds of sport demanding the high level of physical fitness development, athletics, mental strength become more popular nowadays among students of colleges. One of such kind of sport is the rugby $[1,2]$. The influence of this game on athletes' organism is behind of emergence and development of this sport [3, 4]. Collins T. highlighted this. [1]. The popularity of rugby among young people is also demonstrated by the emergence of virtual rugby games. Cummins A. and Craig C. highlighted this [5].

However, the training process of rugby is rather hard. It is connected with injury risk, and risk of overtraining $[6,7]$. The rugby demands on endurance, strength, speed, mental endurance etc [8]. The rugby is also a combative sport which demands the development of a musculoskeletal system [8]. Brown J.C. et al. [9] highlight the necessity of injury prevention in rugby. It is connected with the expensive treatment of athletes, injured in rugby. The improvement of the training process and the search for ways to increase the training efficiency are necessary. Prophylaxis of injury is connected with the improvement of the mechanism of motor action management by a nervous system. Therefore it is possible to presuppose that introduction of levers on the central nervous system into training process will promote the increase in efficiency of

(C) Kozina Zh.L., Kalinicenko V.E., Cretu M., Osiptsov A.V.,

Kudryavtsev M.D., Polishchuk S.B., Inickaya A.S.,

Minenok A.O., 2018

doi:10.15561/20755279.2018.0302 the training process. One of the injury prevention means is the increase in the level of physical fitness of players. Other injury preventions mean is the creation of a positive emotional background of training. Creation of a positive background of training increases adaptive capabilities of rugby veterans [10]. Thus, the positive emotional background will promote the increase in efficiency of the training process of young rugby players.

The music is one of means of the positive background creation in training. It was conducted the range of research concerning the influence of music and sport on the person organism. So, Cabane C. et al. [11] revealed that children during music or sports classes demonstrate higher results in the study. However Cizek E. et al. [12] highlight that music classes demand certain power consumption. Application of music as the mean of increase in the level of physical activity and working capacity was confirmed at the physiological level by Clark I.N. et al. [13]. Authors determined that music can promote diligent participation in the study process. Authors drew a conclusion concerning the efficiency of music application in the programs directed to increase the level of physical activity of humans. Therefore it is possible to presuppose that it is possible to increase fitness with music application in special physical training. The part of a brain (nucleus accumbens) [13] which produces dopamine is activated during listening music: this hormone is influenced by the mood $[13,14]$. The pleasure of listening music is rather a 
difficult phenomenon. Applied music helps the person "to be synchronized" with society and improves collaboration [14].

The research demonstrates that music influences positively on the performance of boring and monotonous tasks. However, music can disturb when studying something new $[14,15]$.

In the researches of Korobeynikov G.V. et al. [16, 17] was determined the high influence of psychophysiological functions on the efficiency of the training process of athletes. In our research, the role of psychophysiological factors in different kinds of the sport was also confirmed [18-20]. This is also relevant for aesthetic sports [18, 21]. It also defines the unity of music and sport as the demonstration of psychophysiological functions [22, 23]. It will promote the increase in efficiency of training process [24-26]. This is relevant for athletic sports (rugby, etc.) [27-29]. The particularly important values in training of young athletes have pedagogical control of the level of physical activities [30-32]; optimization of physical activities [33-35].

The hypothesis of a research consisted in revealing the influence of music on the efficiency of training process (increase in the level of physical fitness of rugby players in 16-17-year-olds).

The purpose of the research is to develop a training technology with the application of music at rugby training of 16-17-year-olds players.

\section{Material and methods.}

Participants. Rugby players $(\mathrm{n}=20)$ from sports club "KhTZ" (16-17-year-olds) participated in a research. Athletes were divided into two groups: control group $(n=10)$, experimental group $(n=10)$. The experiment was conducted from September 25, 2017, to February 22, 2017, in the preparatory period at the stage of specialized basic training. At the beginning and at the end of the experiment, the groups were tested on the level of physical fitness. Results of the first testing demonstrated the identity of groups according to the level of physical fitness ( $\mathrm{p}>0,05)$ (tab. 1). Players were tested in the following tests [25, 26]: $30 \mathrm{~m}$ run; $400 \mathrm{~m}$ run; barbell press in a prone position (maximum value); $3 \mathrm{~km}$ run.

Organization of research. The experimental group trained with music (each athlete used personal earphones). The following exercises were performed to the music: warm-up in the movement, cross run, hit the ball, ball catching, and play with the sports implements. Group exercises were performed without earphones. Music was applied for all athletes. The portable acoustic speaker was applied for this purpose. During performing group exercises the experimental group was separated from the control group. The athletes listened to one track in earphones before the beginning of the game and at the end of training.

The music of the following styles was applied in the experiment: post-grunge, alternative rock, alternative metal, hard rock, and nu-metal. All these styles are characterized by the existence of music bridges in the general background of bass tones; a variety of the guitar sound; non-standard sound changes.

Statistical analysis. Digital material was processed by means of traditional methods of mathematical statistics. It was determined the arithmetic mean of $\mathrm{X}$, average quadratic deviation of $\mathrm{S}$ (standard deviation), a standard mistake (m), assessment of the reliability of differences between parameters of initial and final results. Student t-test was applied with the appropriate level of the significance $(\mathrm{p})$.

The correlation analysis of indicators was carried out when processing primary materials of this research. Data processing was carried out by means of Microsoft Excel, SPSS. Distinctions considered confident at significance value of $\mathrm{p}<0,05$.

Results.

The theoretical justification of the choice of music.

The rock was chosen as the musical style. The nature

Table 1. The indicators of young rugby players physical fitness of experimental $(n=10)$ and control $(n=10)$ groups after the experiment

\section{Statistical indicators}

\begin{tabular}{|c|c|c|c|c|c|c|}
\hline \multirow[t]{2}{*}{ Test } & \multirow[t]{2}{*}{ Group } & \multirow[b]{2}{*}{$\bar{x}$} & \multirow[b]{2}{*}{$S$} & \multirow[b]{2}{*}{$m$} & \multirow[b]{2}{*}{$t$} & \multirow[b]{2}{*}{$p$} \\
\hline & & & & & & \\
\hline \multirow{2}{*}{$30 \mathrm{~m}$ run, sec } & $E$ & 4,37 & 0,21 & 0,07 & $-0,05$ & 0,96 \\
\hline & $C$ & 4,38 & 0,11 & 0,03 & & \\
\hline \multirow{2}{*}{400 m run, sec } & $E$ & 1,06 & 0,02 & 0,01 & $-2,61$ & 0,02 \\
\hline & C & 1,08 & 0,02 & 0,00 & & \\
\hline \multirow{2}{*}{$\begin{array}{l}\text { Barbell press in a prone position, } \\
\text { maximum value, } \mathrm{kg}\end{array}$} & $E$ & 93,00 & 9,78 & 3,09 & 1,49 & 0,15 \\
\hline & $C$ & 88,00 & 4,22 & 1,33 & & \\
\hline \multirow{2}{*}{$3 \mathrm{~km}$ run, $\min$} & $E$ & 11,53 & 0,26 & 0,08 & $-1,33$ & 0,07 \\
\hline & $C$ & 11,77 & 0,51 & 0,16 & & \\
\hline
\end{tabular}

Note: $\mathrm{E}$ - experimental group; $\mathrm{C}$ - control group 
of rock music reflects the condition of mentality when the person overcomes something. Therefore the rock music is applied in gyms. It is known that rugby is physically difficult sport [27, 28]. The rugby demands development of all types of endurance: strong, anaerobic and glycolytic, general, etc. It is possible to presuppose that rock music in training will help athletes to overcome negative feelings. These feelings are connected with the necessity to suffer from high physical loads. Therefore, we decided to apply rock music style in the experimental group of 16-17-yearolds rugby players.

Experimental justification of music application in training process of rugby players.

Creation of educational and training process in rugby with the application of music in training made a positive influence on the level of the general and special physical fitness of players. The analysis of data demonstrates the significant increase in indicators of special and general endurance in athletes of the experimental group (fig. 1, 2 , tab. 1-3). The players of the control group have less expressed change of this indicator. The control and the experimental groups had confident differences in the tests "400 m run", "3 km run" and "barbell press in a prone position" (fig. 1. 2, tab. 4) ( $<<0,001, p<0,01$ ) after carrying out the experiment.

It was revealed the significant increase of indicators of the general endurance ( $3 \mathrm{~km}$ run) and special endurance (400 $\mathrm{m}$ run) in students of the experimental group. The students of the control group had a confident increase in result in $400 \mathrm{~m}$ but in smaller significance value.

\section{Discussion}

The research suggested the hypothesis that application of music in training of young rugby players 16-17-yearolds will promote the efficiency of training process (the level of physical fitness increases). In the research was offered application of music in training (rock style) for improvement of the quality of educational and training process. At the beginning of the research was presupposed that music in training will influence positively on the efficiency of the training process of young rugby players 16-17 year olds. The rugby demands development of all types of endurance (strong, anaerobic and glycolytic, general, etc.) $[27,28,36]$. We presupposed that rock music in training will help athletes to overcome negative feelings. It is connected with the need to suffer high physical loads. The age of athletes is 16-17-year-olds and they are in the condition of the fight (internal and external).

The research revealed the significant increase in indicators of the general and special endurance in students of the experimental group. It was determined the significant differences in groups in the tests of general and special endurance and the maximum strength. Thus, the suggested hypothesis was confirmed.

We explain the efficiency of music with the use of means activating limbic system $[37,38]$. Such means is music. In this case, the organism works more economically due to additional release of endorphins. It promotes concentration on overcoming difficulties and performance of hard work. It helps the athlete to perform work more intensively. The athlete also recovers faster after loads.

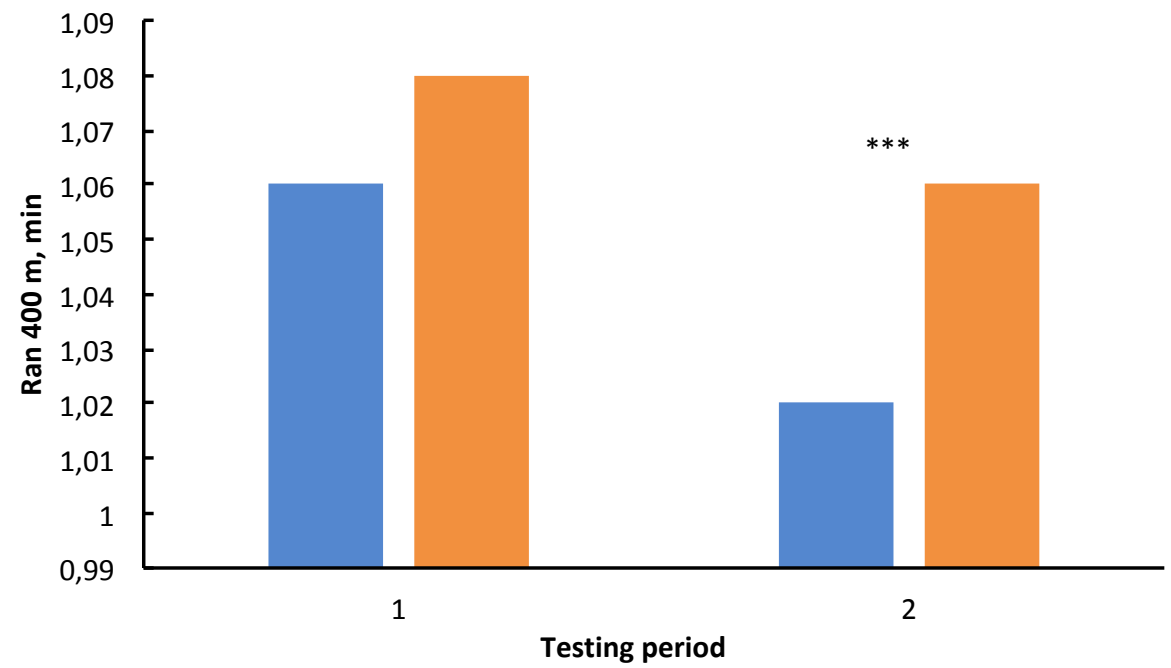

Fig. 1. Results of the test " $400 \mathrm{~m}$ run" by athletes of the experimental and the control groups before and after the experiment:

1 - before the experiment, 2 - after the experiment;

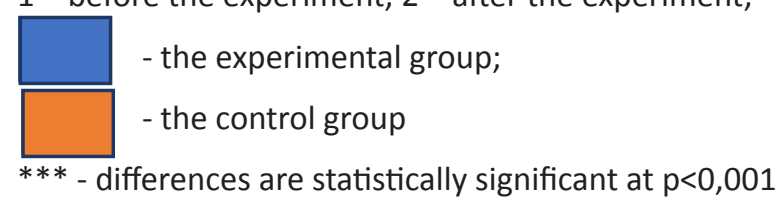




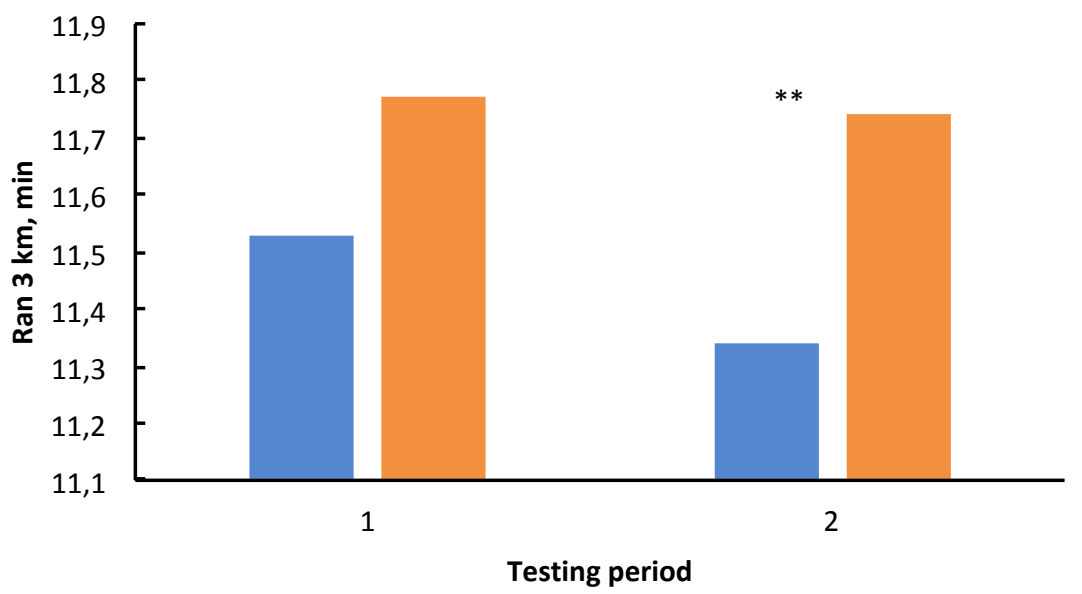

Fig. 2. Results of the test " $3 \mathrm{~km}$ run" by athletes of the experimental and the control groups before and after the experiment:

1 - before the experiment, 2 - after the experiment;

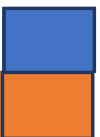

- the experimental group;

- the control group

** - differences are statistically significant at $p<0,01$

Table 2. The indicators of physical fitness of young rugby players of the experimental group before and after the experiment $(n=10)$

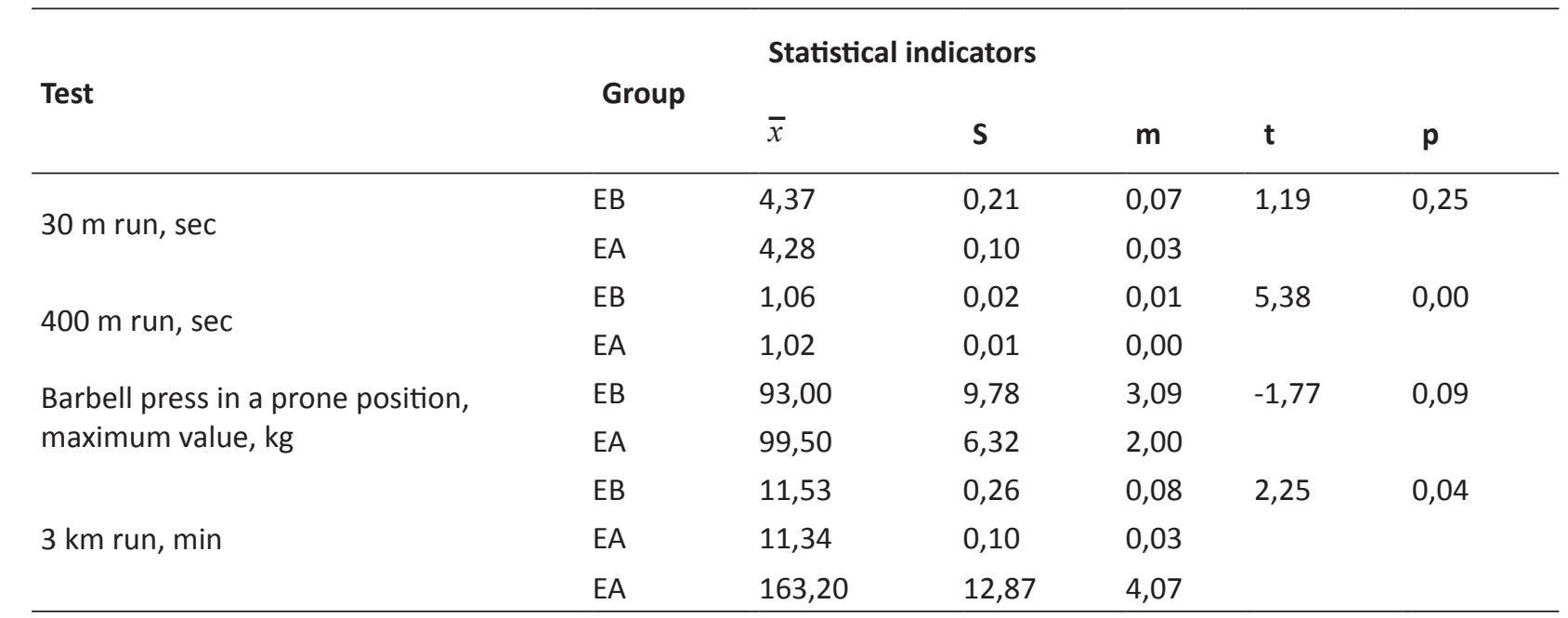

Note: EB - the experimental group before the experiment; EA - the experimental group after the experiment

The application of music gives more pleasure to athletes than «routine» training. Therefore such training is more effective. Generally, music affected the physical fitness of athletes. Listening to the music during performing exercises athletes could carry out exercises longer. For example: in the run, the signal of fatigue was partially blocked by music. The athlete could run quicker the larger distance. Athletes performed the locks of the rival more rigidly: they overcame our fear. During the performance of physical exercises with music, athletes could do in 2-3 times more repetitions with a larger weight. Examinees also noticed that it is much better to perform physical training with music.
The person achieves good results when is training with pleasure and concentrates on overcoming difficulties when performing hard work. Training process in rugby on the development of special endurance is hard work. Therefore the effect of music application was rather essential.

In the test $30 \mathrm{~m}$ run wasn't observed the significant changes. Therefore it is possible to draw a conclusion that application of music influences on the development of the general and special endurance and on the indicators of the maximum strength of rugby players. The music application didn't exert significant influence on the development of high-speed abilities. It can be explained 
Table 3. The indicators of physical fitness of young rugby players of the control group before and after the experiment $(\mathrm{n}=10)$

\begin{tabular}{|c|c|c|c|c|c|c|}
\hline \multirow{2}{*}{ Test } & \multirow{2}{*}{ Group } & \multicolumn{5}{|c|}{ Statistical indicators } \\
\hline & & $\bar{x}$ & S & m & $\mathbf{t}$ & p \\
\hline \multirow{2}{*}{$30 \mathrm{~m}$ run, sec } & $C B$ & 4,38 & 0,11 & 0,03 & 0,53 & 0,60 \\
\hline & CA & 4,35 & 0,09 & 0,03 & & \\
\hline \multirow{2}{*}{400 m run, sec } & $\mathrm{CB}$ & 1,08 & 0,02 & 0,00 & 2,61 & 0,02 \\
\hline & CA & 1,06 & 0,02 & 0,01 & & \\
\hline \multirow{2}{*}{$\begin{array}{l}\text { Barbell press in a prone position, } \\
\text { maximum value, } \mathrm{kg}\end{array}$} & $\mathrm{CB}$ & 88,00 & 4,22 & 1,33 & $-1,85$ & 0,08 \\
\hline & CA & 92,00 & 5,37 & 1,70 & & \\
\hline \multirow{2}{*}{$3 \mathrm{~km}$ run, min } & $\mathrm{CB}$ & 11,77 & 0,51 & 0,16 & 0,13 & 0,88 \\
\hline & CA & 11,74 & 0,50 & 0,16 & & \\
\hline
\end{tabular}

Note: $C B$ - the control group before the experiment; $C A$ - the control group after the experiment.

Table 4. The indicators of physical fitness of young rugby players of the experimental $(n=10)$ and the control $(n=10)$ groups after carrying out the experiment

\begin{tabular}{|c|c|c|c|c|c|c|}
\hline \multirow{2}{*}{ Test } & \multirow{2}{*}{ Group } & \multicolumn{5}{|c|}{ Statistical indicators } \\
\hline & & $\bar{x}$ & S & $\mathrm{m}$ & $\mathbf{t}$ & p \\
\hline 1 & 2 & 3 & 4 & 5 & 6 & 7 \\
\hline \multirow{2}{*}{$30 \mathrm{~m}$ run, sec } & $E$ & 4,28 & 0,10 & 0,03 & $-1,57$ & 0,13 \\
\hline & C & 4,35 & 0,09 & 0,03 & & \\
\hline \multirow{2}{*}{$400 \mathrm{~m}$ run, sec } & $\mathrm{E}$ & 1,02 & 0,01 & 0,00 & $-5,38$ & 0,00 \\
\hline & C & 1,06 & 0,02 & 0,01 & & \\
\hline \multirow{2}{*}{$\begin{array}{l}\text { Barbell press in a prone position, } \\
\text { maximum value, } \mathrm{kg}\end{array}$} & $E$ & 99,50 & 6,32 & 2,00 & 2,86 & 0,01 \\
\hline & C & 92,00 & 5,37 & 1,70 & & \\
\hline \multirow{2}{*}{$3 \mathrm{~km}$ run, min } & $\mathrm{E}$ & 11,34 & 0,10 & 0,03 & $-2,48$ & 0,04 \\
\hline & C & 11,74 & 0,50 & 0,16 & & \\
\hline
\end{tabular}

Note: $\mathrm{E}$ - the experimental group; $\mathrm{C}$ - the control group

by the fact that emergence of changes in a nervous system provoked by music requires the certain time. The exercises on the development of high-speed qualities last rather small periods. Therefore the development of highspeed qualities is less sensitive to musical influence in comparison with endurance.

The proposed method of music application allows increasing the efficiency of training process on the development of the general and special endurance of rugby players of 16-17-year-olds. The analysis of the role of psychophysiological factors in the context of music influence on the efficiency of training process demands more detailed researches.

\section{Conclusions}

1. It is developed the music technology in training of rugby players of 16-17-year-olds and its introduction in the study and training process.

2. It is defined the influence of music on the indicators of special physical fitness of rugby players of 16-17-year- olds.

3. The received data confirm the expediency of music application in training of young rugby players for development of the general and special endurance.

\section{Financing}

The research is conducted according to:

- the research work of Ministry of Education and Science of Ukraine for 2013-2014. «Theoretical and methodical bases of application the information, pedagogical and medical-biological technologies for formation of healthy lifestyle» (№ of the state registration 0113U002003);

- the research work of Ministry of Education and Science of Ukraine for 2015-2016. «Theoretical and methodical bases of means application the information, pedagogical, medical-biological orientation for motor and spiritual development and formation of healthy lifestyle» (№ of the state registration 0115U004036).

- the research work of Ministry of Education and 
Science of Ukraine for 2017-2018. "Theoretical and methodical bases of application of information, medicalbiological and pedagogical technologies for realization of individual physical, intellectual and spiritual potential and formation of healthy lifestyle» (№ of the state registration 0117U000650).

\section{Conflicts of interest}

The authors declare that there is no conflict of interests.

\section{References}

1. Collins T. Rugby's great split: class, culture and the origins of rugby league football. 2nd ed. London: Routledge; 2006.

2. Pretorius J, Pieterse J, Toriola AL, Kubayi NA. Aerobic Fitness of South African Wheelchair Basketball and Rugby Players. Biomedical Research-India. 2015;26(2):249-53.

3. Madrigal L, Robbins J, Gill DL, Wurst K. A Pilot Study Investigating the Reasons for Playing Through Pain and Injury: Emerging Themes in Men's and Women's Collegiate Rugby. Sport Psychologist. 2015;29(4):310-8. doi:10.1123/ tsp.2014-0139

4. Madrigal L, Wurst K, Gill DL. The Role of Mental Toughness in Coping and Injury Response in Female Roller Derby and Rugby Athletes. Journal of Clinical Sport Psychology, 2016;10(2):137-54. doi:10.1123/jcsp.2015-0021

5. Cummins A, Craig C. Design and Implementation of a Low Cost Virtual Rugby Decision Making Interactive. In: DePaolis LT, Mongelli A, editors. Augmented Reality, Virtual Reality, and Computer Graphics, Pt I. Lecture Notes in Computer Science; 2016. P. 16-32.

6. Olsen P, Elliott JM, Frampton C, Bradley PS. Winning or losing does matter: Acute cardiac admissions in New Zealand during Rugby World Cup tournaments. European Journal of Preventive Cardiology, 2015;22(10):1254-60. doi: $10.1177 / 2047487314539433$

7. Orr R, Cheng HL. Incidence and characteristics of injuries in elite Australian junior rugby league players. Journal of Science and Medicine in Sport, 2016;19(3):212-7. doi:10.1016/j.jsams.2015.03.007

8. Dalgalarrondo S. Risk-Taking Apparatus in Professional Rugby. Sociologie Du Travail. 2015;57(4):516-35. doi:10.1016/j.soctra.2015.09.004

9. Brown JC, Viljoen W, Lambert MI, Readhead C, Fuller C, Van Mechelen W, et al. The economic burden of time-loss injuries to youth players participating in week-long rugby union tournaments. Journal of Science and Medicine in Sport, 2015;18(4):394-9. doi:10.1016/j.jsams.2014.06.015

10.Cheng E, Pegg S, Stebbins R. Old bodies, young hearts: a qualitative exploration of the engagement of older male amateur rugby union players in Taiwan. Leisure Studies, 2016;35(5):549-63. doi:10.1080/02614367.2015.1031270

11.Cabane C, Hille A, Lechner M. Mozart or Pele? The effects of adolescents' participation in music and sports. Labour Economics, 2016;41:90-103. doi:10.1016/j. labeco.2016.05.012

12.Cizek E, Kelly P, Kress K, Mattfeldt-Beman M. Factors Affecting Healthful Eating Among Touring Popular Musicians and Singers. Medical Problems of Performing Artists, 2016;31(2):63-70. doi:10.21091/mppa.2016.2013

13.Clark IN, Baker FA, Taylor NF. The modulating effects of music listening on health- related exercise and physical activity in adults: a systematic review and narrative synthesis. Nordic Journal of Music Therapy. 2016;25(1):76-104. doi:10 $.1080 / 08098131.2015 .1008558$

14.Ferriss T. Tools of Titans: The Tactics, Routines, and Habits of Billionaires, Icons, and World-Class Performers. Random House; 2016.
15. Sheppard JR. Sound of Body: Music, Sports and Health in Victorian Britain. Journal of the Royal Musical Association, 2015;140(2):343-69. doi:10.1080/02690403.2015.1075810

16.Korobeynikov G, Korobeynikova L, Iermakov S, Nosko M. Reaction of heart rate regulation to extreme sport activity in elite athletes. Journal of Physical Education and Sport, 2016;16(3):976-981.

17.Korobeynikov G, Mazmanian K, Korobeynikova L, Jagiello W. Psychophysiological states and motivation in elite judokas. Archives of Budo. 2010;6(3):129-136.

18.Kozina Z, Prusik K, Görner K, Sobko I, Repko O, Bazilyuk T, Kostiukevych V, Goncharenko V, Galan Y, Goncharenko O, Korol S, Korol S. Comparative characteristics of psychophysiological indicators in the representatives of cyclic and game sports. Journal of Physical Education and Sport. 2017;(2):648 - 655.

19.Kozina Z, Sobko I, Yermakova T, Cieslicka M, Zukow W, Chia M, Goncharenko V, Goncharenko O, Korobeinik V. Psycho-physiological characteristics of female basketball players with hearing problems as the basis for the technical tactic training methodic in world level teams. Journal of Physical Education and Sport, 2016;16(4):1348-1359. doi:10.7752/jpes.2016.04213

20.Kozina Z, Iermakov S, Crełu M, Kadutskaya L, Sobyanin F. Physiological and subjective indicators of reaction to physical load of female basketball players with different game roles. Journal of Physical Education and Sport. 2017;(1):378-382. doi:10.7752/jpes.2017.01056

21.Kozina Z, Iermakov S, Bartík P, Yermakova T, Michal J. Influence of self - regulation psychological and physical means on aged people's functional state. Journal of Human Sport and Exercise, 2018;13(1), 99-115. doi:10.14198/ jhse. 2018.131 .10

22.Kozina ZL, Iermakov SS, Kozin OV, Kozin SV, Kostyrko AA. Sport and art as a single manifestation of psychophysical capabilities of man. Zdorov'â, sport, reabilitaciâ, 2016;2(3):52-59.

23.Pecen E, Collins D, MacNamara A. Music of the Night: Performance Practitioner Considerations for Enhancement Work in Music. Sport Exercise and Performance Psychology, 2016;5(4):377-95. doi:10.1037/spy0000067

24.Karageorghis CI, Terry PC, Lane AM. Development and initial validation of an instrument to assess the motivational qualities of music in exercise and sport: The Brunel Music Rating Inventory. Journal of Sports Sciences, 1999;17(9):71324. doi:10.1080/026404199365579

25.Kovac Z. Relation between music and physical training. 2011.

26.Doroshenko EY, Svatyev AV, Iermakov SS, Jagiełło W. The use of cardio training facilities in training 7-9 year old judo athletes. Arch Budo Sci Martial Art Extreme Sport, 2017; 13:165-172.

27.King D, Gissane C, Hume PA, Flaws M. The King-Devick test was useful in management of concussion in amateur rugby union and rugby league in New Zealand. Journal of the Neurological Sciences, 2015;351(1-2):58-64. doi:10.1016/j. jns.2015.02.035 
28.King D, Hume P, Gissane C, Clark T. Use of the King-Devick test for sideline concussion screening in junior rugby league. Journal of the Neurological Sciences, 2015;357(1-2):75-9. doi:10.1016/j.jns.2015.06.069

29.Jagiełło M, Iermakov SS, Nowiński M. Differentiation of the somatic composition of students physical education specialising in various sports. Arch Budo Sci Martial Art Extreme Sport, 2017;13:63-70.

30.Kriventsova I, Pashkevych S, Iermakov S, Bartík P, Michal J, Nosko M, Yermakova T. Fitness - aerobic training of 15 - 17 years' age girl students, who have significant risk of deviations in backbone functional state. Journal of Human Sport and Exercise, 2017;12(4), 1289-1297. doi:10.14198/ jhse.2017.124.15

31.Osipov AY, Kudryavtsev MD, Iermakov SS, Jagiello W. Topics of doctoral and postdoctoral dissertations devoted to judo in period 2000-2016-the overall analysis of works of Russian experts. Archives of Budo, 2017;13:1-10.

32. Osipov AY, Kudryavtsev MD, Iermakov SS, Jagiello W. Criteria for effective sports selection in judo schools - on example of sportsmanship's progress of young judo athletes in Russian Federation. Archives of Budo, 2017;13:179-186.

33.Osipov AYu, Kudryavtsev MD, Iermakov SS, Jagiello W. Increase in level of special physical fitness of the athletes specialising in different combat sports (judo, sambo, combat sambo) through of crossFit training. Archives of Budo, 2018; 14 :

34.Jagiello W, Jagiello M, Kalina RM, Barczynski BJ, Litwiniuk A, Klimczak J. Properties of body composition of female representatives of the Polish national fencing team - the sabre event. Biology of Sport, 2017;34(4):401-406. doi:10.5114/ biolsport.2017.70526

35.Kozina ZL, Iermakov SS, Kuzmin VA, Kudryavtsev MD, Galimov GJ. Change of Cortisol and Insulin Content in Blood under Influence of Special Workability Recreation System for Students with High Motor Functioning Level. Research Journal of Pharmaceutical Biological and Chemical Sciences. 2016;7(2):1068-1077.

36.Quarrie KL, Raftery M, Blackie J, Cook CJ, Fuller CW, Gabbett TJ, et al. Managing player load in professional rugby union: a review of current knowledge and practices. British Journal of Sports Medicine, 2017;51(5):421-530. doi:10.1136/bjsports-2016-096191

37.Tan ZJ. Study on the Role of Music in Aerobics. 2011.

38. Vogelsang L, Anold S, Schormann J, Wubbelmann S, Schredl M. The Continuity Between Waking-Life Musical Activities and Music Dreams. Dreaming, 2016;26(2):13241. doi: $10.1037 / \mathrm{drm} 0000018$

\section{Information about the authors:}

Kozina Zh.L.; (Corresponding author); http://orcid.org/0000-0001-5588-4825; Zhanneta.kozina@gmail.com; Department of Olympic and Professional Sports and Sports Games, H.S. Skovoroda Kharkiv National Pedagogical University; Alchevskyh str. 29, Kharkov, 61002, Ukraine.

Kalinicenko V.E.; http://orcid.org/0000-0002-9109-5089; H. S. Skovoroda Kharkiv National Pedagogical University; Alchevskyh str. 29, Kharkov, 61002, Ukraine.

Cretu Marian; http://orcid.org/0000-0003-1934-0534; Faculty of Science, Physical Education and Informatics; University of Pitesti; Str. Targul din Vale, nr.1, 110040 Pitesti, Arges, Romania.

Osiptsov A.V.;; http://orcid.org/0000-0002-1640-2632; Mariupol state University; Budivelnykiv Ave., 129a, Mariupol, 87500, Ukraine.

Kudryavtsev M. D.; http://orcid.org/0000-0002-2432-1699; Siberian Federal University; 79, Svobodny pr., Krasnoyarsk, 660041, Russia.; Reshetnev Siberian State University of Science and Technology; Office A-406, 31, Krasnoyarsky Rabochy Av., 660014, Krasnoyarsk, Russia.; The Siberian Law Institute of the Ministry of Internal Affair of Russia; Rokossovskia str., 20, Krasnoyarsk, 660131, Russia.; Krasnoyarsk State Pedagogical University of V.P. Astafyev; Ada Lebedeva Street, 89, Krasnoyarsk, 660049, Russia

Polishchuk S.B.; http://orcid.org/0000-0001-8275-4567; Department of Olympic and Professional Sports and Sports Games, H.S. Skovoroda Kharkiv National Pedagogical University; Altshevskih str. 29, Kharkov, 61002, Ukraine.

IInickaya A.S.; http://orcid.org/0000-0001-5835-8847; Department of Olympic and Professional Sports and Sports Games, H.S. Skovoroda Kharkiv National Pedagogical University; Altshevskih str. 29, Kharkov, 61002, Ukraine.

Minenok A.O.; http://orcid.org/0000-0002-4145-4039; Faculty of Physical Education, National University "Chernigiv collegium" T. G. Shevchenko; Hetman Polubotko str., 53, Chernigiv, 14013, Ukraine.

Cite this article as: Kozina ZhL, Kalinicenko VE, Cretu M, Osiptsov AV, Kudryavtsev MD, Polishchuk SB, Ilnickaya AS, Minenok AO. Influence of music on the level of physical fitness of the students practicing rugby (rugby players students). Physical education of students, 2018;22(3):120-126. doi:10.15561/20755279.2018.0302

The electronic version of this article is the complete one and can be found online at: http://www.sportedu.org.ua/index.php/PES/issue/archive

This is an Open Access article distributed under the terms of the Creative Commons Attribution License, which permits unrestricted use, distribution, and reproduction in any medium, provided the original work is properly cited (http://creativecommons.org/licenses/by/4.0/deed.en).

Received: 10.03 .2018

Accepted: 04.04.2018; Published: 27.06.2018 